\title{
The European Union's Rule of Law Agenda: Identifying Its Core and Contextualizing Its Application
}

\author{
Elaine Mak $^{1} \cdot$ Sanne Taekema ${ }^{1}$
}

Published online: 7 March 2016

(c) The Author(s) 2016. This article is published with open access at Springerlink.com

\begin{abstract}
Monitoring the rule of law performance of EU member states presupposes that the EU has a clear idea of what is meant by the rule of law. Theoretically, however, the conceptualization of this notion has proven difficult, leading to a wide range of differing approaches. Moreover, the application of a common rule of law concept in a multilevel legal context creates its own difficulties. As the starting point for this contribution, we identify a core meaning of the rule of law based on the work of Philip Selznick and Martin Krygier. They see the reduction of the arbitrary use of power as the central value and point to the importance of a contextual approach to realizing that value: reducing arbitrariness may require very different concrete measures from one society to another. We examine what common idea of the rule of law is projected by the European Union in its rule of law agenda, looking specifically at two important instruments, the Justice Scoreboard and the Better Regulation programme. Using the contextual approach to rule of law, we then examine whether the core meaning of this concept is recognizable here, and whether efforts are already made to allow for the inclusion of contextual elements. Our analysis clarifies that the two instruments support the core notion of the rule of law by enhancing the quality of political debates in the EU. However, underlying economic assumptions and approaches as well as political forces form a constant threat to the realization of elements of participation and separation of powers.
\end{abstract}

Elaine Mak: Endowed Professor of Empirical Study of Public Law, in particular of Rule-of-Law Institutions, at Erasmus School of Law (Erasmus University Rotterdam).

Sanne Taekema: Professor of Jurisprudence at Erasmus School of Law (Erasmus University Rotterdam).

Sanne Taekema

taekema@law.eur.nl

1 Erasmus University Rotterdam, Rotterdam, The Netherlands 


\section{Introduction}

The rule of law is a fundamental value of the European Union $(\mathrm{EU})^{1}$ and a criterion for the accession of new Member States, requiring the guarantee of the independence of their judiciary and the quality of legislation. ${ }^{2}$ However, instruments developed with the aim of monitoring respect for the rule of law in the EU's Member States do not always seem to give a clear expression of the value of the rule of law.

The aim of our paper is to conceptualize rule of law as a core value in the context of EU monitoring instruments. In our paper, we depart from a twofold central question: To what extent is a core notion of rule of law recognizable in EU instruments to monitor the judiciary and to improve regulation, and what does it mean to contextualize the rule of law with regard to these instruments? The first building block of our approach is theoretical: building on a framework that sees rule of law as a distinctive legal value that needs to be approached contextually. The second building block is an account of two instruments in which rule of law values should be at work: the Justice Scoreboard and the Better Regulation programme. We chose these two instruments because they aim to improve two institutional practices, judging and lawmaking, that are both core concerns of the European Union. Moreover, they are sufficiently different to generalize the rule of law approach beyond the concrete problems of judicial organization and regulatory procedure. We will assess the way in which rule of law figures in these instruments by way of three concrete questions derived from the theoretical framework: (1) Is the core notion of rule of law as the reduction of the arbitrary exercise of power recognizable in these instruments?; (2) If not or only in a rudimentary way, can the core notion be linked to more specific elements of these instruments?; (3) What room for contextualization do the instruments give?

We will first briefly discuss the theoretical framework. Next, we will present the two instruments and study the rule of law aspects of these instruments, addressing the three concrete questions formulated above. In the article's concluding remarks, we will reflect on the implications of our findings with regard to the realization of the rule of law in the EU.

\section{Theoretical Framework}

Rule of law theories conceptualize the rule of law in a variety of ways. ${ }^{3}$ The debate over formal versus substantive theories is by now well-known: the question whether the rule of law only includes elements such as predictability and legality or also substantive equality and human rights has not been resolved, although there are

\footnotetext{
1 Article 2 TEU.

2 http://ec.europa.eu/enlargement/policy/policy-highlights/rule-of-law/index_en.htm. Accessed 17 February 2016.

${ }^{3}$ Compare Tamanaha (2004).
} 
interesting positions trying to bridge the gap. ${ }^{4}$ What the contributions to the debate all share is a focus on the elements or principles that the rule of law comprises. There is, however, an alternative account which takes the purpose and value of the rule of law as such as the central concern. The prime representative of this position is Martin Krygier, who give a specific value-based, contextual account of the rule of law. His theory relies heavily on the earlier work of Philip Selznick; ${ }^{5}$ both theories can be labelled 'teleological' as their central concern is the telos or purpose the rule of law serves. ${ }^{6}$ The theory is not only teleological, but draws heavily on socio-legal insights as well. There are two main building blocks to the theory: the formulation of the comprehensive ideal of the rule of law and the account of how context matters for the rule of law. In Selznick's words: "Only the analysis of particular institutions or social spheres will tell us what rules and procedures are appropriate; and only then can we take into account special needs and circumstances without shortchanging or corrupting more comprehensive standards of legality and morality."7

The first pillar of the theory, which will be used as a criterion for assessment of the EU instruments, is the formulation of the ideal or value of the rule of law. Both Selznick and Krygier argue for the rule of law as a distinctive 'master ideal'. In Selznicks work the ideal of legality or rule of law is the master ideal for the practice of law. ${ }^{8}$ This means that we cannot understand law without its orientation towards realization of that ideal. In slightly different terms, Krygier approaches the rule of law by identifying its point or immanent purpose. ${ }^{9}$ Both formulate the central meaning of the rule of law in terms of the reduction of arbitrariness: legal instruments, such as, but not limited to, rules, should limit the possibility that those in power exercise that power in an arbitrary way. ${ }^{10}$ For Selznick and Krygier, this is a moral as well as a legal value, akin to Fuller's internal morality of law. ${ }^{11}$ There are subtle differences in formulation, however, which deserve attention because they are relevant to the scope of the rule of law argument. Selznick repeatedly defined the rule of law as the "progressive reduction of arbitrariness in positive law and its administration', ${ }^{12}$ which is a demanding, open-ended idea of law oriented towards improvement of its realization of this ideal. Selznick stresses that this connects what he calls 'negative' and 'positive' ideas of the rule of law, ${ }^{13}$ which we equate with the formal and substantive elements. More importantly, the rule of law is taken as an ideal that calls for ever-increasing realization. By contrast, Krygier emphasizes a more modest notion of the rule of law, distinct from the other 'good things' law can realize, and predominantly concerned with one problem: the arbitrary use of

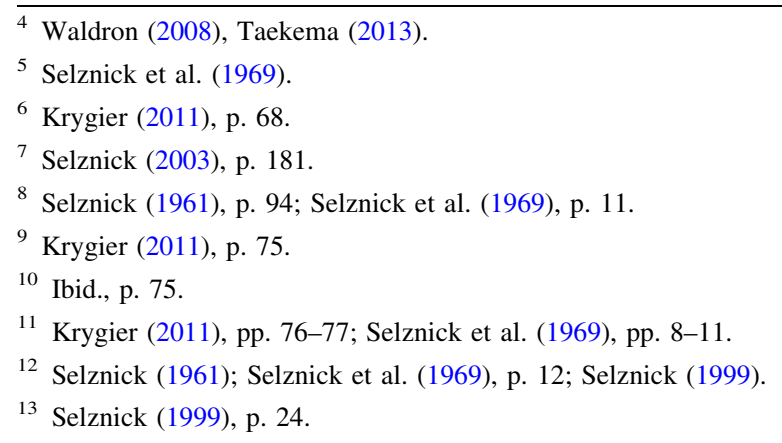


power. ${ }^{14}$ Where Selznick sees a continuity between the rule of law and other values, Krygier delineates the values that make up the rule of law itself from the benefits that can follow from the rule of law for other values. Both approaches have merit. We can agree with Selznick that it is difficult to draw the line between rule of law and other values law serves, such as justice and equality. However, Krygier has a good point that there are some values that seem to be an integral part of the rule of law, while others can be distinguished from it, at least analytically, if not in practice. In further fleshing out the theory, we therefore take the position that the reduction of arbitrary exercise of power is central, but that this should be viewed progressively. This entails that it is not enough to check whether a threshold of guarantees against arbitrariness is passed, but that the potential for further realization of the rule of law as also contributing to values with which it has affinity, such as democracy and human rights, is investigated as well. The latter goal may sound overly ambitious, but this ambition should be understood in light of the other building block of the theory.

The second pillar of the theory is a commitment to a contextual understanding of the rule of law. Both Selznick's and Krygier's basic commitment is to the study of law in society, which is particularly relevant to the study of rule of law, because the failure or success of rule of law projects depends only partly on the internal workings of the legal system. If there is widespread corruption, having a legal apparatus that limits the possibility of arbitrariness through its rules is of little use. ${ }^{15}$ This means that the societal context in which the law operates is a large factor in understanding the rule of law more concretely. Selznick has shown that realization of the rule of law depends greatly on the social and cultural setting in which the rule of law is put to work. Interestingly, he did not limit his investigation of rule of law to state institutions, but researched affinities with rule of law values in industrial corporations. ${ }^{16}$ In the American context of the late 1960s there were developments which supported realization of the rule of law in this non-state environment. Here, the idea of progressive realization of the rule of law found a congenial setting. On the other hand, he also highlights the possibility that a legal culture may be weak or under threat. ${ }^{17}$ Krygier, in part by applying these kinds of arguments to the problems of post-communist states, made the argument that the rule of law is located in social traditions. This makes it very hard to introduce particular institutions or forms of law, coming from a strong rule of law tradition, to a country with a different legal culture to which the rule of law is alien. ${ }^{18}$ A contextual approach to the rule of law needs to take these social and cultural backgrounds into account: both the problems of the rule of law and the possible solutions are contextdependent. Thus, we need to combine the formulation of the general value of the

\footnotetext{
14 Krygier (2012), p. 35; Krygier (2011), p. 75.

15 As they say in the Congo, 'Why pay a lawyer, if you can buy a judge?'; as narrated by Dirk-Jan Koch, describing his experience working for an NGO in De Congo Codes (2014).

16 Selznick et al. (1969).

17 Selznick (2003), p. 179.

18 Krygier (2009), pp. 69-70.
} 
rule of law with the socio-legal context in which it operates in order to figure out what form of rule of law is appropriate.

If we then formulate the rule of law as the ideal of progressively reducing the arbitrary exercise of power, we also need to sketch some more concrete, variable, purposes that can serve as pointers for achieving the ideal. By unpacking the idea of non-arbitrariness, we can identify four aspects. ${ }^{19}$ In literature on non-arbitrary decision-making, a first central feature is the rationality of decisions: simply deciding at will without good arguments makes decisions arbitrary. ${ }^{20}$ Whereas the notion of reasoned decision-making applies to all exercise of power, the second aspect of predictability applies specifically to rules. The third aspect is fairness in concrete decision-making, i.e. when deciding upon individual cases administratively or judicially, which requires a contextual assessment. The fourth aspect is accountability to those affected, including the possibility to voice arguments or complaints. ${ }^{21}$ All of these aspects are open-ended, matching Selznick's idea of rule of law as a progressive ideal. Although they do not directly proclaim substantive values, they each point to central values, of moral reason, legal certainty, justice and democracy, with which the rule of law has close affinity. The idea of reducing arbitrariness is thus not only recognizable in the classic rule of law element of predictability of rules. It also requires reasoned argument and sensitivity to the context of the decision, and it requires possibilities for citizens to be part of the process. The latter means including participation as a possible way to realize the ideal. Including participation may seem surprising because it seems to include a democratic element in the rule of law ideal, which is usually kept separate. We understand it as the possibility of individuals to have a voice in legal procedures, at different stages. With participation we therefore mean that power becomes less arbitrary if there is genuine engagement of the powerful actor with the actors affected by its conduct. Finally, the identification of these aspects of reduction of arbitrariness leads us to an idea of balance of powers. Although this cannot be derived from the meaning of reduction of arbitrariness as such, it is a crucial condition in a legal order to make non-arbitrariness possible. Balance of powers, of course, reintroduces an idea of trias politica: concentration of power, regardless of the institution concerned, engenders opportunities for arbitrariness. A focus on balance of powers rather than separation of powers seems preferable to achieve the contextual embedding of the rule of law and aligns with the notion of accountability. $^{22}$ However, some elements of a stricter separation such as the

\footnotetext{
19 Cimini (2005) derives this list of four elements from the context of American administrative law. Selznick associates rationality with a more positive, less rule-oriented, rule of law vision (1999, p. 27). The other three aspects relate to principles in well-known lists [e.g. Bingham (2010); Raz (1979)].

20 There is also criticism of this element, Vermeule argues that under conditions of uncertainty this requirement cannot be upheld and an unreasoned choice may be unavoidable A. Vermeule, 'Rationally Arbitrary Decisions (in Administrative Law)', Harvard Public Law Working Paper No. 13-24, 2013. Available at SSRN: http://ssrn.com/abstract=2239155. Accessed 17 February 2016.

21 Waldron (2008). In a different theoretical framework, this element is seen as crucial within Global Administrative Law (Kingsbury 2009).

22 Bellamy (2011) shows how balance of powers links to a republican rather than a liberal vision of constitutionalism, in which political equality is central rather than freedom from interference. The notion of accountability has close affinity with this vision.
} 
independence of judicial decision-making seem necessary in all legal orders. The variability can be found in the ways in which institutional independence is reached, which may need extra guarantees in cultures in which the rule of law is fragile.

With this elaboration of the rule of law in mind, the issue of realization of the ideal needs to be addressed. How can the state of the rule of law be assessed? In rule of law policy, attempts are made to measure rule of law performance of states or agencies. The search for objective criteria is combined with a comparative focus: where do rule of law measures succeed or fail? Rule of law measurement and ranking is a salient feature of this development. ${ }^{23}$ Especially in the context of global governance, the rule of law has made the list of issues assessed by way of indicators. Our analysis can therefore also draw on the growing literature on the use of indicators, of which the work of Davis, Merry and Kingsbury is the most relevant. ${ }^{24}$ They characterize indicators as follows: 'An indicator is a named collection of rankordered data that purports to represent the past or projected performance of different units'. ${ }^{25}$ Indicators simplify raw data and are used to evaluate performance on the basis of standards. In both of the EU instruments discussed in this article, indicators matter: very directly in the Justice Scoreboard, which is an indicator-based instrument, in different, more indirect ways in Better Regulation, which is used to compare countries but also makes use of impact assessments which use indicators.

The Justice Scoreboard, firstly, is meant as a point of reference for the EU to issue recommendations to Member States regarding the functioning of their justice systems. The Better Regulation programme, secondly, provides guidelines to ensure the quality of legislation developed by the EU institutions. In the next sections, we will analyze to what extent these two instruments reflect the core notion of the rule of law and give room for contextualization in connection with differences between Member States regarding the realization of the rule of law ideal.

\section{Assessing the Rule of Law Aspects of the Justice Scoreboard}

This section first describes the main characteristics of the EU Justice Scoreboard. Next, taking into account the three questions formulated in the Introduction of this article, we will assess to what extent the core notion of the rule of law is recognizable in the Justice Scoreboard or can be linked to specific elements of this instrument. Furthermore, the compliance of the Scoreboard itself with this notion of the rule of law will be examined, taking into account the role of contextualization to fit the plurality of values and social contexts in the EU. Finally, we will address the role of the Justice Scoreboard in monitoring the rule of law in EU Member States, by analyzing the country-specific recommendations which were formulated for two Member States (Hungary and Italy).

\footnotetext{
${ }^{23}$ On a global scale, the most important one is the World Justice Project's Rule of Law Index. For an analysis, see Urueña (2015). More generally on indicators Davis et al. (2012).

24 Merry et al. (2015); Davis et al. (2012).

25 Davis et al. (2012), p. 73.
} 


\subsection{The Justice Scoreboard}

On 9 March 2015, EU Commissioner Věra Jourová, Commissioner for Justice, Consumers and Gender Equality presented the Justice Scoreboard 2015. This third edition builds further on the previous editions, which were published in 2013 and 2014. In the foreword of the 2015 Justice Scoreboard, Commissioner Jourová emphasizes the necessity of effective national justice systems 'for enforcing the Union's laws in practice and contributing to economic growth'. ${ }^{26}$

The Scoreboard focuses on three indicators: efficiency, quality and independence. ${ }^{27}$ Efficiency, firstly, is measured in terms of the length of proceedings, the clearance rate and the number of pending cases. Quality, secondly, is connected to improvement measures, e.g. training, monitoring, budget, human resources and the availability of information technology and alternative dispute settlement. The measurement of independence, thirdly, is held to concern legal safeguards for the structural independence of national judiciaries. New elements introduced in the 2015 edition of the Scoreboard include the use of IT, the role of alternative dispute resolution and the equal balance of male and female judges. Furthermore, the 2015 Justice Scoreboard includes the presentation of identified trends concerning the three measured aspects of justice systems. ${ }^{28}$

The socio-legal context of Member States is taken into account in the Justice Scoreboard in the following way. As a first step, the Scoreboard is based on 'objective, reliable and comparable data' concerning the functioning of the justice systems of the Member States. ${ }^{29}$ Consecutively, the results from the analysis of data are used in country-specific assessments in the framework of the EU's economic policy coordination (the European Semester), taking the form of bilateral communication with authorities and stakeholders in Member States. In these assessments, attention is paid to the particularities of the legal system and to the context of each Member State. Based on the assessment, the European Commission may give country-specific recommendations. ${ }^{30}$ Data concerning the justice systems also played a role in the Economic Adjustment Programmes concerning Greece, Portugal and Cyprus, which contained conditions related to justice reform. ${ }^{31}$ Despite this room for contextualization, the 2015 Scoreboard emphasizes that minimum requirements of efficiency, quality and independence should be met, regardless of differences in workloads between the judiciaries of the Member States. ${ }^{32}$ It seems that the Commission aims to use reports from the Member States regarding their reforms to fine-tune the indicators used in the Scoreboard and to provide guidance regarding activities that are common to more Member States. ${ }^{33}$

\footnotetext{
26 European Commission 2015, The 2015 EU Justice Scoreboard, COM(2015)116 final, Foreword.

272015 EU Justice Scoreboard, p. 6.

282015 Justice Scoreboard, p. 6.

29 Ibid., p. 5. See further below, Sect. 3.2.

${ }^{30}$ Ibid., pp. 4-5.

31 Ibid.

32 Ibid., p. 6.

33 Ibid., p. 4.
} 
The number of Member States which receive country-specific recommendations concerning the improvement of their justice system has steadily increased, numbering six in 2012, ten in 2013 and twelve in 2014. ${ }^{34}$ Measures taken on the basis of the recommendations concern the operation of justice systems, e.g. modernization of management processes, use of information technology, development of alternative dispute settlement and training of judges. They also concern structural measures, e.g. restructuring of court organization or reform of civil procedure. $^{35}$

This far-reaching effect of the Justice Scoreboard on the organization of justice systems, and on national economic policies, in the EU justifies an analysis of this instrument in light of the ideal of the rule of law.

\subsection{Recognition of the Core Notion of Rule of Law?}

We have defined the rule of law as the ideal of progressive reduction of arbitrary exercise of power, an ideal which encompasses the aspects of rationality, predictability, fairness and accountability and the realization of which requires a balance of powers. The core value of reducing arbitrariness is not explicitly recognizable in the Justice Scoreboard. However, the notion of rule of law can be identified in specific elements of the instrument, connected with the three indicators of efficiency, quality and independence.

The connection of the notion of rule of law with elements of the Justice Scoreboard is most clear with regard to the measurement of legal safeguards of structural independence of the judiciary, which relates to the principle of balance of powers. Further points of reference related to the judiciary's institutional position can be identified in elements which concern the preconditions for the adequate functioning of justice systems, such as judicial training, human resources and budget. The Justice Scoreboard also acknowledges the significance of the length of proceedings, essential to the guarantee of a 'fair trial' ${ }^{36}$ and therewith to curbing the arbitrary use of public power. However, the connection with prevention of arbitrariness in justice systems is less explicit with regard to the measurement of clearance rates, the number of pending cases or the availability of information technology.

It is important to note that the presentation of the second version of the EU Justice Scoreboard in March 2014 coincided with the adoption of a new Rule of Law Framework by the European Commission. The then-President of the Commission Barroso explained that the framework's aim is to provide a more adequate instrument for reacting to systemic threats to the rule of law in a specific Member State, allowing avoidance of the harsher instrument of preventive or sanctioning measures taken under Article 7 of the Treaty on the European Union. ${ }^{37}$

\footnotetext{
342014 EU Justice Scoreboard, p. 5; 2015 EU Justice Scoreboard, p. 4.

35 Ibid.

36 This notion can be connected to the requirement of Article 6 of the European Convention on Human Rights, which states that judgments should be handed down within a reasonable time.

37 Barroso, JMD 2014, 'Remarks by President Barroso on the future of Justice and Home affairs and the Rule of Law initiative', press conference Strasbourg, 11 March 2014.
} 
The Framework clarifies that the Commission uses a broad definition of the rule of law, based on the case law of the Court of Justice of the EU and the European Court of Human Rights, and focusing on 'a system where laws are applied and enforced'. 38

In the area of justice, measures taken in the past years include the development of EU rights for victims of crime, stronger fair trial rights in criminal procedures and personal data protection. ${ }^{39}$ These measures, focusing on access to justice and the protection of private life, can be connected to the central meaning of the rule of law. However, the Future Justice Agenda, presented by Commissioner Reding together with the Rule of Law initiative, is less explicit about this legal value. It places the rule of law in service of economic policy goals related to trust, mobility and growth. ${ }^{40}$ This approach is visible also in the Justice Scoreboard, which puts particular emphasis on the contribution of effective justice systems to economic growth.

The European Commission has stated that it considers the Rule of Law Framework and the Justice Scoreboard as two separate instruments. The Rule of Law mechanism can be used by the Commission to actively support the guarantee of the rule of law across Europe by addressing systemic threats to the rule of law in Member States. It should be noted that the EC's competence to act in this regard has been challenged by the European Council and the effectiveness of the mechanism, which leans on the expected outcomes of dialogue, has been put into question by legal scholars. ${ }^{41}$ Indeed, the EC's cautious approach in addressing rule of law violations in Hungary and Poland in the past years can be criticized for its inadequacy in dealing with regimes that deliberately choose to act against EU values. $^{42}$ The Justice Scoreboard might enable the EU to address shortcomings of national justice systems in a different way. It is not an instrument specifically for ensuring the guarantee of the rule of law. ${ }^{43}$ Yet, the Scoreboard provides data which can be used by the Commission to recommend certain strategies to Member States in the framework of economic policy coordination, which might benefit compliance with the rule of law ideal.

Keeping this background to the instrument in mind, we will turn our attention to the analysis of rule of law aspects in the practical experience with the Justice Scoreboard. This analysis will first address the realization of the ideal of the rule of

\footnotetext{
38 European Commission 2014, 'European Commission presents a framework to safeguard the rule of law in the European Union', press release Strasbourg, 11 March 2014.

39 V. Reding, 'Towards a true European area of Justice: Strengthening trust, mobility and growth', press release Strasbourg, 11 March 2014, p. 3.

40 Ibid.

41 D. Kochenov and L. Pech, 'From Bad to Worse? On the Commission and the Council's Rule of Law Initiatives', EU Law Analysis, 19 January 2015, available at eulawanalysis.blogspot.nl.

${ }^{42}$ Regarding Hungary, see Sect. 3.4.1 below. Regarding Poland, the Commission has initiated a dialogue with the Member State under the new 'pre-Article 7 procedure'. See European Commission 2016, 'College Orientation Debate on recent developments in Poland and the Rule of Law Framework: Questions \& Answers', fact sheet Brussels, 13 January 2016.

43 European Commission 2014, 'The 2014 EU Justice Scoreboard: Questions \& Answers', memo Brussels, 17 March 2014.
} 
law in the production of the Justice Scoreboard and next the realization of this ideal in the formulation of country-specific recommendations by the European Commission.

\subsection{Assessing the Production of the Justice Scoreboard}

In order to establish the EU Justice Scoreboard, quantitative data from the Council of Europe's Commission for the Evaluation of the Efficiency of Justice (CEPEJ) are combined with information from inter alia the World Bank, the European Network of Councils for the Judiciary and pilot field studies on consumer and competition law. ${ }^{44}$

As a first point of criticism, it is unclear how the definitions of 'efficiency', 'quality' and 'independence', applied by the Justice Scoreboard, have been established. The 2013 EU Justice Scoreboard merely presents these three elements as standard indicators defined by CEPEJ and directs readers to the CEPEJ website for a further explanation. ${ }^{45}$ This argumentation comes across as rather weak. Notwithstanding the undoubted quality and authority of CEPEJ research, it might be expected of the drafters of the Justice Scoreboard to provide a stronger justification of the selection of indicators in light of the rule of law framework of the EU. In this regard, the rule of law aspect of rationality, in the sense of reasoned decisionmaking, could have been realized to a fuller extent in the production of the Justice Scoreboard.

This criticism becomes even more pertinent when considering the balancing of rule of law values and economic values, which underlies choices for the organization of justice systems. ${ }^{46}$ Improvements of justice systems on the basis of evaluations such as the Justice Scoreboard can only be achieved if the actors involved in the development of reforms and practices share a common set of values regarding ethical behavior and good government. ${ }^{47}$ Concerning the functioning of justice systems, the optimal use of scarce resources is a matter of common interest to governments, judges, court managers and citizens alike. Economic values and rule of law values overlap for example regarding the guarantee of timeliness of judgments. ${ }^{48}$ However, the interests of different actors can diverge in other respects, for example concerning the degree of autonomy which should be granted to individual judges in organizing their case management. ${ }^{49}$ The contextual assessment of this balancing of values might lead to a different definition of the three indicators for the EU than for the Council of Europe, which represent different geographical spheres, different motives for transnational cooperation and different models of governance. For this reason, it can be argued that the EU should develop its proper

\footnotetext{
442015 EU Justice Scoreboard, p. 5.

45 European Commission 2013, The 2013 EU Justice Scoreboard, COM(2013)160 final, p. 4.

46 See Mak (2008).

47 Mohr and Contini (2014), p. 851.

48 Ibid., pp. 849 and 851; see also Mak (2008), p. 733.

49 Mak (2008), p. 730.
} 
indicators for the Justice Scoreboard, based on EU values, in order to enable a contextualized assessment of each Member State's justice system.

The Scoreboard's methodology has been criticized further for its inaccurate use of data, in particular concerning the use of information on national justice systems collected by CEPEJ. CEPEJ's data collection regarding judicial reforms and practices in Member States of the Council of Europe is established on the basis of different national research approaches and is specifically meant to provide an overview only. ${ }^{50}$ The Scoreboard presents this CEPEJ information in the form of a ranking of justice systems and without a clarification of the differences between national research approaches. In this way, relevant aspects of comparative methodology as well as contextual explanations for the data concerning each Member State are overlooked. ${ }^{51}$ In light of our presented framework for achieving the ideal of the rule of law, this criticism can be connected with the aspect of fairness. After all, a fair account and comparison of the justice systems of the EU Member States requires that data are sufficiently contextualized.

With regard to accountability and participation, the interaction between the European Commission and Member States is of importance. The European Commission has organized cooperation with the Member States regarding the Justice Scoreboard in an informal group of contact persons, composed of a representative of the judiciary and a representative of the ministry of Justice from each Member State. This group was established in 2013 in order to facilitate the collection of data for the Scoreboard and 'to promote the exchange of best practices on the effectiveness of justice systems' ${ }^{52}$ The input of this group in the collection of data for the Justice Scoreboard is mentioned for the first time in the methodology of the 2015 Scoreboard. ${ }^{53}$

Notwithstanding the Commission's efforts, the cooperation of Member States in collecting data for the Justice Scoreboard has problematic aspects. Firstly, there is no check on the accuracy of the presented data. Moreover, Member States can be less inclined to cooperate with the EU if they think they lack 'ownership' regarding the processing, interpretation and analysis of data. ${ }^{54}$ Indeed, it appears that some Member States were less willing to provide information for the 2014 EU Justice Scoreboard than they were for the 2013 Scoreboard. An unattributed EU source admitted to the EUobserver, an independent online newspaper, that '[i]n certain graphs, it is true that we have less data' ${ }^{55}$ This incompleteness of the used data undermines the rationality of conclusions derived from the study of the Justice Scoreboard. A further analysis reveals that the problem is substantial. Data on certain matters reported on in 2010 was not delivered concerning 2012 by six Member States: Cyprus, Germany, Hungary, Luxembourg, Romania and Spain.

\footnotetext{
50 Mohr and Contini (2014), p. 846.

51 Ibid., pp. 848-847.

522015 EU Justice Scoreboard, p. 4, footnote 7.

53 Ibid., p. 5.

54 Serban (2015), p. 217.

55 N. Nielsen, 'EU Justice Scoreboard Upsets Some Member States', EUobserver, 17 March 2014, available at euobserver.com.
} 
Three of these Member States, namely Hungary, Romania and Spain, had received recommendations on the basis of the 2013 Scoreboard. ${ }^{56}$ Cyprus participated in an Economic Adjustment Programme, in which conditions set by the EU were connected to justice reforms in the Member State. ${ }^{57}$ The UK refuses to provide information for the Justice Scoreboard altogether. ${ }^{58}$ The UK Justice Secretary Chris Grayling has defended this refusal on the basis of criticism of the EU's approach regarding the Scoreboard. He questioned the competence of the European Commission to produce the Scoreboard as well as the usefulness of the instrument besides arguably more effective reports of the Council of Europe's CEPEJ. ${ }^{59}$ Furthermore, Grayling criticized the unresponsiveness of the European Commission with regard to reservations of Member States concerning the Scoreboard, expressed in the EU Justice and Home Affairs Council. ${ }^{60}$

\subsection{Assessing Country-Specific Recommendations Based on the Justice Scoreboard}

Rule of law aspects in the application of the Justice Scoreboard to EU Member States, and the role of contextualization in this regard, come to the fore in the country-specific recommendations developed in the framework of the European Semester. ${ }^{61}$ These recommendations have a basis in Article 121 of the Treaty on the Functioning of the EU. However, this legal framework leaves a large margin of discretion to the European Commission and European Council in deciding on the degree of detail of recommendations for different Member States and on the consequences in case a Member State does not follow up on the recommendations. ${ }^{62}$ Also, it is not clear to what extent Member States need to justify actions taken or the absence of action with regard to recommendations. In these two respects, the rationality of decision-making regarding the improvement of justice systems in the EU can be criticized.

Regarding participation, a noteworthy difference in the 2015 Scoreboard when compared with the 2014 document concerns the description of the interaction between the Commission and the Member States. The 2014 Scoreboard mentioned the Commission's role in identifying justice as a priority area for the Member States which received recommendations. ${ }^{63}$ The 2015 Scoreboard describes the interaction between the Commission and the Member States as a dialogue and emphasizes the autonomy of the Member States in setting their funding priorities, taking into

\footnotetext{
562014 EU Justice Scoreboard, p. 6.

572015 EU Justice Scoreboard, p. 2, footnote 1.

58 Nielsen, see above n. 54.

59 European Scrutiny Committee of the House of Commons 2014 (35888) 7910/14 (30 April 2014).

60 Ibid.

61 See above, Sect. 3.1.

62 European Commission 2015, 'Q\&A: Country-specific recommendations 2015', fact sheet Brussels, 13 May 2015.

632014 EU Justice Scoreboard, p. 6.
} 
account the country-specific recommendations regarding their justice system. ${ }^{64}$ This change of approach might be related to the resistance against the Scoreboard expressed in the refusal of several Member States to provide data regarding their national justice systems.

Hungary and Italy constitute two illustrative cases for clarifying the rule of law aspects in the application of the Justice Scoreboard. Both Member States have received country-specific recommendations in consecutive years regarding the improvement of their justice systems.

\subsubsection{Hungary}

The ranking of Hungary in the 2013 EU Justice Scoreboard, in which the country did well especially with regard to the length of proceedings ${ }^{65}$ and relatively well with regard to judicial independence, ${ }^{66}$ was met with surprise. Then-EU Commissioner Reding explained that the data used in the 2013 Scoreboard concerned the judicial system of Hungary in 2010, before the significant constitutional amendment of 2011 and important judicial reforms took place. ${ }^{67}$ A further analysis clarifies, however, that the Justice Scoreboard currently is not sufficiently equipped for identifying failures in the Member State's realization of the rule of law in its national justice system.

In the past years, Prime-Minister Orbán's Fidesz government has drawn attention with controversial reforms regarding the retirement age of judges and the competences of the President of the National Judicial Office concerning case allocation and the transfer of judges as well as with the appointment of 'friends' of the Fidesz party on important institutional positions. ${ }^{68}$ The European Commission started infringement procedures against Hungary in 2012 under Article 258 of the Treaty on the Functioning of the European Union for violating its obligations under EU law. This alleged violation concerned inter alia the lowering of the retirement age of judges from 70 to 62 without an objective justification. ${ }^{69}$

Based on the Commission's assessment of the national situation, Hungary was one of the ten Member States which received country-specific recommendations in the follow-up of the 2013 Justice Scoreboard. The Commission's recommendations for Hungary concerning the period 2013-2014 included the advice to '[a]ddress concerns about the independence of the judiciary' and related this recommendation

\footnotetext{
642015 EU Justice Scoreboard, p. 4.

652013 EU Justice Scoreboard, pp. 6-11.

66 Ibid., p. 21. Hungary ranked at nr. 72 out of 144 countries in the world concerning judicial independence generally and nr. 32 out of 97 countries in the world concerning the independence of civil justice. The source of these data was the World Economic Forum.

67 N. Nielsen, 'Hungary in Surprise Ranking on EU Justice Scoreboard', EUobserver, 27 March 2013, available at euobserver.com.

68 Ibid.

69 European Commission 2012, 'European Commission launches accelerated infringement proceedings against Hungary over the independence of its central bank and data protection authorities as well as over measures affecting the judiciary', press release Strasbourg, 17 January 2012. See also Gyöngyi (2013), p. 13.
} 
to more general advice concerning the creation of a 'supportive business environment' ${ }^{70}$ Interestingly, in 2014 and 2015, Hungary was absent from the list of countries which received recommendations concerning the national justice system. ${ }^{71}$ This might be explained by the 'other road' taken by the Commission with regard to Hungary, i.e. the initiation of infringement procedures. ${ }^{72}$ However, the absence of recommendations could also be linked to the inaccuracy or incompleteness of presented data in the Justice Scoreboard. In the 2014 EU Justice Scoreboard, Hungary's performance was assessed as relatively good regarding efficiency and quality of the justice system in comparison with the other Member States. Concerning judicial independence, only the perception as measured by the World Economic Forum was taken into account by the Scoreboard. ${ }^{73}$ In 2015 , research regarding this indicator was expanded to include a comparative overview of structural independence. However, part of the presented information was not collected by the EU itself but instead derived from a study by the European Network of Councils for the Judiciary. ${ }^{74}$ An assessment of Hungary's relative performance can be found in the 2015 Justice Scoreboard with regard to two aspects only, notably not including the composition of the Council for the Judiciary. ${ }^{75}$ Moreover, the presented data for this indicator provide relatively little guidance for Member States regarding the most suitable way of organizing their national judicial system in order to realize judicial independence. In this respect, the absence of clear similarities regarding legal safeguards could explain the short and rather vague nature of the conclusions regarding judicial independence ${ }^{76}$ in comparison to the conclusions concerning efficiency and quality of justice systems. ${ }^{77}$

A shortcoming of the Justice Scoreboard in relation to the ideal of the rule of law, which presents itself here, is the implicit assumption that constitutional values regarding the balance of powers and political respect for the judiciary's position are well-established in the EU Member States. If this were true, the Scoreboard could operate as an adequate instrument for enhancing notions of efficiency and quality of justice. However, the Hungarian case shows that this assumption is mistaken and makes clear how instruments such as the current Scoreboard, in consequence of a false basic assumption, fail to identify serious flaws in the realization of a national justice system which lives up to the ideal of the rule of law. This case underlines the importance of contextualization and a weakness of analyses using indicators as a point of reference: 'Although checklist-based rule-of-law indicators may seem an advance over fuzzy definitions, only forensic legal analysis can tell how a constitutional order works in practice. ${ }^{78}$

\footnotetext{
${ }^{70} \operatorname{COM}(2013) 367$ final, p. 7.

712015 EU Justice Scoreboard, p. 4; COM(2015)266 final.

72 See most recently European Commission 2015, 'Commission opens infringement procedure against Hungary concerning its asylum law', press release Brussels, 10 December 2015.

732014 EU Justice Scoreboard, p. 26.

742015 EU Justice Scoreboard, p. 37.

75 Ibid., pp. 37 and 41.

76 Ibid., p. 43.

77 Ibid., pp. 19 and 36.

78 See also Lane Scheppele 2013, p. 562.
} 


\subsubsection{Italy}

Italy received country-specific recommendations concerning the national justice system in 2012, 2013 and 2014. ${ }^{79}$ In its 2013 Recommendation, the European Commission observed: 'Completing the civil-justice reform by swiftly implementing the revision of courts' organization and reducing the excessive duration of casehandling, court backlogs and high level of litigation is necessary to improve the business environment. ${ }^{, 80}$ Furthermore, the Commission noted the need of further promotion of alternative dispute settlement and the need to effectively fight against corruption. ${ }^{81}$ The Commission recommended inter alia timely implementation of reforms through legislation and executive action, reinforcement of public administration and reduction of the length of court proceedings. ${ }^{82}$ The Commission observed in 2014 that the identified inefficiencies had not been resolved and recommended a timely monitoring of implemented reforms. ${ }^{83}$

The Commission's country report on Italy's macroeconomic situation, presented in February 2015, includes the observation that '[d]espite marginal improvements, inefficiencies in the public administration and justice remain. According to several national and international sources, corruption is high, which damages the economy'. ${ }^{84}$ The Commission recognizes that some improvements to the justice system have been achieved, including a reform of the judicial map, the increase of specialization within the court system and the introduction of mandatory mediation in certain civil and commercial cases. ${ }^{85}$ The first experiences seem promising, in particular concerning the use of digital means. Still, the Commission finds that no clear efficiency gains are visible with regard to the backlog of cases and concludes that Italy's business environment, for this reason, is not sufficiently open to foreign investment. $^{86}$

This case, similar to the case of Hungary, clarifies that the socio-legal context of Member States is taken into account only in a superficial manner in the application of the Justice Scoreboard. No precise recommendations are formulated for example regarding the most suitable way of fighting corruption in the Italian judicial system. Once more, the analysis reveals limitations of the Justice Scoreboard related to the incompleteness of information on certain matters and the absence of a contextual analysis of the comparative findings. Because of these weaknesses, the Scoreboard does not provide clear practical or normative guidance to the Member States concerning the improvement of their justice systems. This case study of Italy, like the study on Hungary, further indicates that the Commission makes more recommendations concerning the enhancement of the efficiency of the justice

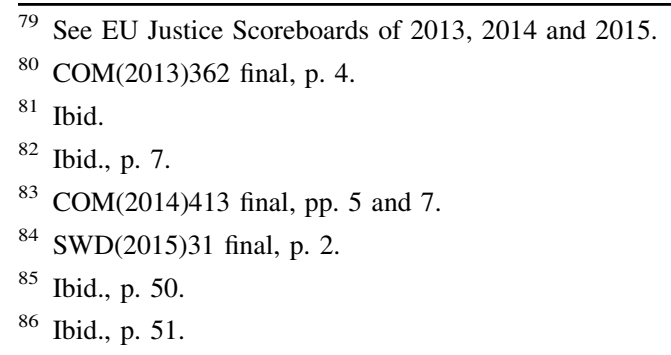


system than concerning the guarantee of judicial independence. This difference supports the hypothesis that, in cases of conflicting values, ${ }^{87}$ the instrument of the Scoreboard focuses more (and possibly too much) on the promotion of economic values than on the guarantee of the value of the rule of law in the EU.

\subsection{Analysis and Conclusions Concerning the Justice Scoreboard}

The functioning of the justice systems of Member States is of importance for the effective implementation of EU law by the courts in Member States, which are the 'decentralized Community judges'. ${ }^{88}$ More generally, justice systems are important for the guarantee of effective judicial protection to citizens and businesses, protected by article 47 of the Charter of Fundamental Rights of the EU and part of the constitutional traditions common to the Member States. ${ }^{89}$ However, the analysis of the EU Justice Scoreboard clarifies that this instrument does not so much connect with constitutional values related to the interests of citizens, such as the right to an effective judicial remedy and a fair trial, but rather emphasizes neo-liberal values related to the interests of businesses. Indeed, the EU Justice Scoreboard connects justice reforms to the aim 'to improve business climate and to overcome the sovereign debt and financial crisis' ${ }^{90}$ The application of this instrument in economic policy coordination, in combination with the EC's reluctance to apply the Rule of Law framework for addressing systemic threats to the rule of law in Member States, gives cause for concern regarding the realization of the rule of law ideal in the justice systems within the EU.

When connecting the analysis of the EU Justice Scoreboard to the specific aspects of the ideal of the rule of law regarding 'progressive development', 'participation' and 'balance of powers', the following concluding observations can be made.

Firstly, the purpose of the Justice Scoreboard fits with the ideal of the rule of law in the sense that the collection of data regarding national justice systems is used to formulate suggestions for improvement. That is: the instrument aims at achieving progress. However, progress in the sense of improvement of justice systems can only be achieved on the basis of reliable, comprehensive and comparable data concerning the Member States. The methodology for the production of the Justice Scoreboard raises concerns in this regard, because the Scoreboard relies to a large extent on secondary sources of information while differences concerning national research approaches and concerning the contextual analysis of data are not sufficiently acknowledged. The more robust methodology used in data collection for the Rule of Law Index, developed by the World Justice Project, could serve as an example in this respect. ${ }^{91}$

\footnotetext{
87 See above, Sect. 3.2.

88 Amtenbrink and Vedder (2013).

89 European Commission 2014, The 2014 EU Justice Scoreboard, COM 2014, 155 final, p 2.

902014 EU Justice Scoreboard, p 3; see also 2015 EU Justice Scoreboard, p 2.

91 See Urueña (2015), p. 82.
} 
Secondly, the European Commission performs relatively well regarding the realization of the ideal of the rule of law through participation. With regard to the production of the EU Justice Scoreboard, the involved actors include national and European governments and judicial authorities as well as experts within the national judiciaries and ministries of Justice and researchers involved in field studies on the organizational setting of application of EU law by national courts. Still, the applied methodology and cooperation with Member States require improvement. Moreover, the role and influence of all of these actors needs to be scrutinized in order to confront the risk of capture of the debate by a specific actor. In particular, the data consulted concerning the perception of the judiciary by civil society, such as a survey conducted by the World Economic Forum, currently might focus too much on the views of businesses and take insufficient account of the views of citizens.

Finally, the contribution of the Justice Scoreboard regarding the curbing of arbitrary use of power can be criticized. In particular, the indicators of 'efficiency', 'quality' and 'independence' do not seem adequate with regard to the realization of the rule of law in terms of a balance of powers. The three indicators focus on economic values and quantifiable information and leave aside justice-related and qualitative aspects concerning for example the fairness of proceedings or the comprehensibility of judgments. For this reason, the Justice Scoreboard gives only partial insight into the realization of the ideal of the rule of law in EU Member States. This limitation is demonstrated in the follow-up on the Scoreboard with regard to Hungary and Italy. A long list of recommendations is presented for Italy, focusing on inefficiencies in the organization of court proceedings and the detrimental effect of these inefficiencies for business and investment. By contrast, Hungary has received no more than one general recommendation to address concerns regarding judicial independence, despite the 'imbalance' of powers resulting from the Fidesz party's control of the political and legal system. In this regard, the Commission's action is at odds with the criticism and pressure exerted through infringement procedures initiated against Hungary on the basis of the EU Treaties. The distinction made between the EU's Rule of Law Framework and the Justice Scoreboard seems artificial in this respect. What signal is given to a Member State if it ranks well in the Scoreboard, inter alia in terms of legal safeguards for the independence of the judiciary, while clear failures to uphold judicial independence in practice can be identified in the Member State's political and social context?

\section{Assessing the Rule of Law Aspects of Better Regulation}

Complementary to the monitoring of justice systems by The Justice Scoreboard, Better Regulation is a programme focussing on the regulatory task of the EU and its Member States. Here too, assessment from a rule of law perspective seems warranted, because the quality of legislation, and rulemaking more broadly, may clearly contribute to non-arbitrariness in the sense discussed above. 


\subsection{Better Regulation Programme}

The Better Regulation programme was initiated by the European Commission in 2001 to improve the quality of EU legislation. The programme focusses on improving procedures of lawmaking in a number of ways. A central element of the programme is the instrument of impact assessment (IA), which can be defined as 'the systematic and thorough ex ante assessment of proposals for policies or legislation, covering impacts that are external to government, often making use of economic tools such as cost-benefit analysis'. ${ }^{92}$ Other elements include public consultation, ex-post evaluation and reduction of administrative burdens. ${ }^{93}$ Following the 2002 Action Plan on Better Regulation, which aimed to develop 'a common legislative culture within the Union', Member States have developed new regulatory policies and cooperated in particular in the IA framework. ${ }^{94}$ More recently, what is now labeled 'smart regulation' by the European Commission has come to include elements which focus primarily on reducing the complexity and burdens of regulation for businesses and citizens; the Regulatory Fitness and Performance Programme is the primary umbrella for this. ${ }^{95}$ The commitment of the European Commission to better regulation is also evident in the appointment of Commissioner Timmermans as a First Vice-President in charge of better regulation, inter-institutional relations, rule of law and human rights, with the particular brief of coordinating better regulation within the Commission. ${ }^{96}$

Better Regulation as such does not have a basis in the European Treaties; it is a policy strategy to coordinate and rationalize the European Union's regulatory efforts. ${ }^{97}$ While Better Regulation has a clear economic goal in terms of ensuring competitive market strategies, it also expresses standards for the legitimate exercise of public power. ${ }^{98}$ However, with regard to the latter aspect it is not entirely clear how Better Regulation, based on requirements of public administration, relates to constitutional requirements of legislative acts. From the perspective of the rule of law, a point of concern is that Better Regulation focuses on substantive and formal tests of procedures in terms of economic and public administration criteria, but seems to ignore the constraining function of public law on rule-making. Whereas this framework could foster the deliberative element in procedures, it might not provide sufficient constraints on the influence of powerful private stakeholders. ${ }^{99}$ As a central instrument for the accountability of EU regulation, Better Regulation merits further scrutiny in terms of rule of law.

\footnotetext{
92 Meuwese and Popelier (2011), p. 456.

93 European Commission 2014, 'Regulatory Fitness and Performance Programme (REFIT): State of Play and Outlook', Communication COM(2014)368 final, pp. 13-15.

94 Meuwese and Popelier (2011), p. 456.

95 COM(2014)368.

96 F. Ferraro, Briefing for the hearings of European Commissioners-designate, First Vice-President Timmermans. European Parliamentary Research Service, PE 532.921, 2014.

97 Radaelli and Meuwese (2010), p. 143.

98 Meuwese and Popelier (2011), p. 457.

99 Ibid., p. 458.
} 
In order to make a meaningful assessment of Better Regulation in terms of the rule of law, it is fruitful to turn to the fairly extensive research done, especially on regulatory impact assessments, from a political science and regulatory studies perspective. As said, Better Regulation is a policy initiative by the European Commission bureaucracy, and this provenance is accompanied by a decided dominance in research of disciplines focusing on policy and administration. The advantage of using these studies is that significant empirical work can be drawn upon which analyzes both the quality and the use of impact assessments. ${ }^{100}$ It does require a further analysis in terms of rule of law, by assessing what the findings mean in terms of reduction of arbitrariness, especially in the exercise of power.

Although explicit acknowledgment of the rule of law as a distinctive and overarching value for regulation is absent, as is to be expected in such a broad public administration agenda, other concerns can be taken as a basis for involvement of rule of law values. As in the discussion of the Justice Scoreboard, we will consider whether the core notion of the rule of law is recognizable in Better Regulation and to what extent context-sensitivity is part of it. In relation to Better Regulation we assess the particular instruments of impact assessment and public consultation in terms of rule of law in three ways. ${ }^{101} \mathrm{We}$ investigate the idea that impact assessments can increase rationality and predictability of decision-making, the importance of balance of powers in the use of impact assessments, and the place of public consultations both in the impact assessments themselves and in EU policy more generally. The idea of increasing predictability aligns the policy with the formal aspect of the rule of law: the classic notion that the subjects of the law (or regulation) know what to expect. Balance of powers plays an important role as a check on arbitrary power, as explained in Sect. 2, and is highly relevant in the politically charged context of making regulation. Thirdly, public consultation is a form of participation which can be seen as a (limited) form of constraining power, because it requires that regulators take the arguments of subjects seriously. The use of consultation can be connected most directly to the contextualization of the rule of law.

\subsection{The Character and Goals of Impact Assessment in the Context of Better Regulation}

To start with the character of impact assessment as such, it is evident that the main idea behind it is the rationalization of policy choices, and as such it can be viewed as an effort to reduce arbitrariness in policymaking. ${ }^{102}$ Rationality here takes on a specific meaning: regulatory impact assessments (RIA) predominantly make use of methodologies of cost-benefit analysis and assessment of administrative burdens. ${ }^{103}$ There is a definite push towards streamlining Better Regulation in European states,

\footnotetext{
$\overline{100}$ E.g. Cecot et al. (2008), Hertin et al. (2009), Dunlop et al. (2012).

101 The aspect of fairness distinguished in Sect. 2 is not included, because it is less relevant in the context of adopting general rules.

102 Alemanno (2011), p. 486.

103 Hertin et al. (2009), p. 417.
} 
with the OECD as a main driving force. The OECD regularly monitors Better Regulation programmes and has clear preferences for a uniform Better Regulation policy supervised by a national agency. ${ }^{104}$ The methodology of RIA is to score costs and benefits by attaching numerical values to criteria and ranking alternatives. ${ }^{105}$ Much then depends on the quality of data processing in a particular RIA, which may differ greatly. ${ }^{106}$ In the study of Cecot et al., the quality of EU impact assessments is evaluated by making use of a similar economic methodology as the assessments themselves, measuring quality in terms of the inclusion of quantified data in the impact assessment. ${ }^{107}$ Thus, the importance of quantifiable data in impact assessment is assumed rather than evaluated in its own right. Rationality of regulatory procedure then employs a particular version of reasoned decisionmaking, namely basing analysis on quantifiable standardized data.

From a rule of law perspective, the value of the standard methodologies of impact assessment is an open question, in part because the quality of the executed impact assessments is variable. ${ }^{108}$ However, even if the quality of the impact assessments themselves is good, and it does seem to improve, ${ }^{109}$ the relevance of quality in terms of the rule of law may be limited. If a good assessment is shelved or ignored by policy makers, its quality does nothing to enhance the predictability of regulation. Achievement of predictability depends much more on the use that is made of impact assessments.

\subsection{Uses of Impact Assessment}

How impact assessments are used, shifts the focus to the different actors involved and the issue of balance of powers. For this rule of law issue, we can draw on a body of research from policy studies. A meta-analysis of 31 case studies in the UK and $E U^{110}$ uses a framework of four usages of regulatory impact assessment (RIA): 'political, instrumental, communicative, and perfunctory usages' ${ }^{111}$ It turns out that the different usages overlap, and that the actors involved in the implementation of RIA have significant influence on the outcomes of the process. ${ }^{112}$ For instance, a stakeholder that sees the content of the RIA as detrimental to its interests can

\footnotetext{
104 The OECD completed their EU 15 project in 2012, in which it assessed Better Regulation in the original 15 EU member states (OECD 2008, Better Regulation in Europe: An OECD assessment of regulatory capacity in the 15 original member states of the EU. Project objectives, methodology, process, output, at http://www.oecd.org/gov/regulatory-policy/44952962.pdf. Accessed 17 February 2016). This was preceded by a review of the 12 then 'new' member states of the EU.

105 The OECD advises on how to conduct an RIA (OECD 2008, Introductory Handbook for Undertaking Regulatory Impact Analysis, at www.oecd.org/gov/regulatory-policy/44789472.pdf. Accessed 17 February 2016). For a critical analysis of RIA, see Hertin et al. (2009).

106 Hertin et al. (2009).

107 Cecot et al. (2008), p. 406.

108 Ibid., p. 420.

109 Ibid., p. 412.

${ }^{110}$ Dunlop et al. (2012).

111 Ibid., p. 23.

112 Ibid., p. 40.
} 
politicize the use of the RIA, sometimes going so far as to order a counter-RIA. ${ }^{113}$ Many RIAs are perceived as simply fulfilling a formal requirement, with the policy already having been adopted or taken elsewhere: the perfunctory usage. ${ }^{114}$ These findings raise questions about the balance of powers of the actors involved in these processes: who can have a decisive influence, who can counter that influence, etc.?

From a policy perspective, the answers are mainly interesting as an empirical matter, but for the rule of law we need to ask whether it is possible to institutionalize such powers and counter-powers. In some contexts, this seems to be possible: Radaelli and Meuwese show how the introduction of impact assessments by the European Commission, which was meant to enhance the transparency of EC proposals for Parliament and Council, ${ }^{115}$ had the effect of creating a new balance among the Directorates-General within the bureaucracy of the European Commission. By requiring the inclusion of impacts on business, environment, health etc. the procedure facilitates, what they call, 'partisan mutual adjustment' because each Directorate-General makes the case for the interest that is part of its own policy field. ${ }^{116}$ Although this is not the standard way of looking at balance of powers, it seems to reduce the ad-hoc character of policymaking and may therefore be beneficial in terms of rule of law. However, from a broader institutional perspective this may be problematic, because it further strengthens the role of the European Commission. If the expertise required for carrying out impact assessments is concentrated at the Commission, the other actors such as Parliament and Council may regard this as threatening and disregard the impact assessment for that reason only. ${ }^{117}$ Thus, a costly impact assessment which might have been a good contribution to the decision-making process, may become a barrier. Ownership of the impact assessment is therefore important: if it is used strategically by the agency submitting the proposal to bolster its policy choice, it may be counterproductive. ${ }^{118}$ One way to minimize this danger is by including consultation in the process of impact analysis.

\subsection{Public Consultation}

This brings us to the third issue, the role of consultation. Public consultation seems positive for rule of law values: casting the net for participation wide (for instance by the introduction of online consultation) this instrument is geared to enhance accountability of lawmaking. Here, the European Union is at the forefront of developments by making systematic use of consultation mechanisms. ${ }^{119}$ In 2014 , a

\footnotetext{
113 Ibid., p. 34.

114 Ibid., p. 35.

115 Radaelli and Meuwese (2010), p. 140.

116 Ibid., p. 147.

117 Compare Dunlop et al. (2012).

118 Hertin et al. (2009), p. 418.

119 Compare Hertin et al. (2009), p. 419.
} 
public consultation was held on the new guidelines for impact assessment. ${ }^{120}$ The openness to stakeholder views is again affirmed as one of the fundamental principles of impact assessment. However, recent research on the use of open consultation by the European Commission shows that stakeholder engagement is biased towards business and industry representatives. ${ }^{121}$ Although there is no procedural barrier against participation by citizens and civil society organizations, they lack the means, importantly financial means, to engage seriously and repeatedly. ${ }^{122}$ This is one reason why other forms of stakeholder engagement than open consultation may be preferable; Brown and Scott point to the establishment of 'standing panels' of stakeholders for policy fields as a better way of achieving real dialogue. ${ }^{123}$ The issue of consultation may be the most direct concern for a contextual approach to the rule of law. Standard procedures at the EU are open to democratic participation but the culture of lobbying and the presence of industrial and business interests is such that much more needs to be done for the absence of citizens and NGOs to be addressed. Here, the sociological approach that Krygier and Selznick advocate seems highly necessary: progress in terms of the participatory aspect of the rule of law can only be made if the cultural base for participation is strengthened. However, drawing on Selznick we may need to be cautious here: if there is no potential for an alternative way of involving stakeholders, setting out rules and procedures is futile. Given the dominance of lobbyists and experts, much would be required to foster change, including sustained attention for rule of law values as applying to private actors as well. ${ }^{124}$ Additionally, the broader discourse on regulation may need to change: moving away from the reductive discussion of red tape and administrative costs to a broader discussion of the values that matter to European citizens.

\subsection{Analysis and Conclusions Concerning Better Regulation}

Better Regulation is a relevant concern if we regard rule of law as reducing arbitrary exercise of power. Regulatory power is the main manifestation of the power of public actors such as the European Commission, so assessment of it in terms of rule of law values seems warranted. However, it is hard to draw clear conclusions from the discussion of Better Regulation, mainly because the characteristics of the programme seem to support the rule of law at first sight, but turn out to be problematic upon further exploration.

Impact assessment, with its social science and economic approaches of costeffectiveness and cost-benefit analysis, could increase predictability but it harbors the danger of outsourcing public and political decisions to bureaucrats and experts

\footnotetext{
${ }^{120}$ European Commission 2014, '2014 Revision of the European Commission Impact Assessment Guidelines. Public Consultation document', at http://ec.europa.eu/smart-regulation/impact/docs/iag_pc_ questionnaire_en.pdf. Accessed 17 February 2016.

121 Marxsen (2015).

122 Ibid., p. 278.

123 Brown and Scott (2011), pp. 479-480.

124 Compare Selznick et al. (1969).
} 
who perform impact assessments according to their own, technocratic, standards. ${ }^{125}$ The political use by other political actors such as the European Parliament may alleviate the technocratic bias, but it may lead to a battle of the IAs similar to the battle of the experts in court. The lack of a European demos or European citizenship problematizes the idea of public consultation, and further thought needs to be given to the problems (and possible ways of dealing with them) this generates in terms of rule of law values in the context of European society.

Most elusive, but also most serious from a rule of law perspective, is the background assumption that regulation needs to serve economic interests by being cost-effective. ${ }^{126}$ Various aspects of this discourse add up to a pervasive logic in which it is hard even to formulate the importance of other values. The way to include rule of law values seems to be through politicizing the process, but this creates a bias towards a democratic rule of law which may shortchange some of its other aspects. This logic of economic rationalization also limits the possibility to raise questions regarding the socio-legal context of Better Regulation, because the diversity that comes with a contextual approach is understandably problematic when standardization of regulatory procedures is the main goal. In this regard, the political uses of IAs can be valued positively: questioning the appropriateness of an IA may allow for the introduction of contextual factors in the discussion. On the other hand, political uses of Better Regulation policies can also reduce discussions to superficial attention, masking political power play.

\section{Conclusion}

The two examined EU instruments both refer to a rule of law concept, in which the reduction of arbitrary use of power is recognizable. However, the translation of this rule of law concept in the development of specific indicators and policies has taken place in light of an underlying economic aim. The consequences of this combination of distinctive legal values with economic purposes for the shaping of the instruments is visible in the focus on quantifiable elements in the EU Justice Scoreboard and the emphasis on impact assessments, and the input of experts in this respect, in the Better Regulation programme. These particular aspects entail risks for the realization of the rule of law in terms of the guarantee of judicial independence and in terms of capture of regulatory processes by specific actors respectively.

It seems that the European Commission and Council take the point of view that a more robust guarantee of the rule of law through EU instruments is too ambitious as an aim in the current phase of the process of legal integration in Europe and the inherently political nature of this process. ${ }^{127}$ Regulating the justice systems of the

\footnotetext{
125 Compare Ambrus (2014), esp. Chs. 15-18.

126 For example, the OECD states 'However, regulation should only proceed if it is expected to improve society's economic and social welfare' (OECD 2008, Introductory Handbook for Undertaking Regulatory Impact Analysis, at www.oecd.org/gov/regulatory-policy/44789472.pdf. Accessed 17 February 2016).

127 See also F. Timmermans, 'The European Union and the Rule of Law', speech Tilburg, 31 August 2015 .
} 
EU uniformly is a particularly sensitive matter, and as experiences with the European Arrest Warrant have shown cooperation in this area is difficult. ${ }^{128}$ However, the effectiveness of current rule of law initiatives, which emphasize the role of dialogue, can be put into question with regard to Member States that deliberately distance themselves from EU values. In this respect, the instrument of the Justice Scoreboard requires further development, both concerning its production and its application, in order to provide an adequate means for promoting the realization of shared standards for justice systems in the EU. Better Regulation, too, might not live up to the task at hand if its sole added value consists of serving as a point of reference regarding the quality of regulation and as stimulating the discussion on how to achieve this quality.

More specifically, a risk attached to the Justice Scoreboard is that the EU uses scores to push through specific reforms in Member States or, vice versa, that Member States highlight a good score on specific aspects of the Scoreboard to downplay serious deficiencies concerning other aspects of their justice system. In particular, good scores on efficiency should not be used to mask problems concerning the guarantee of judicial independence. In a similar vein, reference to the logics of Better Regulation might be used to mask deficiencies in public consultation, resulting in the adoption of administratively sound rules which lack a sufficient connection with the substantive values supported by European citizens.

With regard to contextualization, we recognize two forms. The Justice Scoreboard aims to set standards for the Member States, allowing a differentiated approach with regard to the implementation of these standards. By contrast, the Better Regulation programme is aimed first of all at the EU itself and might have additional effects on regulation policies in the Member States, but here a contextual approach is not directly visible. Our idea is that different forms of contextualization (geographical and other) need to be given shape to have meaningful contextualization of the rule of law values. However, we also recognize that it is very difficult to achieve contextualization for all Member States in the pan-European context. In this respect, the warning given by Krygier and Selznick in rule of law theory retains its relevance in practice. Therefore, limitations in this regard should be acknowledged. Based on our analysis, both the experiences with the Justice Scoreboard and with the Better Regulation programme clarify that the development of points of reference for justice systems and legislation in the EU context could have an added value, but is currently severely hampered by the influence of political interests and the obvious difficulties in translating these points of reference into concrete solutions and practices.

In sum, the analyzed EU monitoring instruments have potential to enhance the quality of political debates at the EU level and between the EU and Member States. In this way, these instruments could support the core notion of the rule of law concerning the reduction of the arbitrary use of power. However, economic assumptions and approaches underlying the monitoring instruments as well as political interests influencing the interaction between the EU and the Member States form a constant threat to the realization of the rule of law ideal.

128 Wolff (2013), p. 122. 
Acknowledgments We thank Kim Lane Scheppele and all the participants of the workshops on Monitoring the rule of law in the EU in Amsterdam (24 November 2014) and Rotterdam (23 March 2015) for their valuable comments.

Open Access This article is distributed under the terms of the Creative Commons Attribution 4.0 International License (http://creativecommons.org/licenses/by/4.0/), which permits unrestricted use, distribution, and reproduction in any medium, provided you give appropriate credit to the original author(s) and the source, provide a link to the Creative Commons license, and indicate if changes were made.

\section{References}

Alemanno A (2011) A meeting of minds on impact assessment: when ex ante evaluation meets ex post judicial control. Eur Public Law 17:485-505

Ambrus M, Arts K, Hey E, Raulus H (eds) (2014) The role of 'experts' in international and European decision-making processes: advisors, decision makers or irrelevant actors? Cambridge University Press, Cambridge

Amtenbrink F, Vedder H (2013) Recht van de Europese Unie. Boom Juridische uitgevers, Den Haag

Bellamy R (2011) Constitutionalism. In: Badie B, Berg-Schlosser D, Morlino L (eds) International encyclopedia of political science, vol 2. Sage, London, pp 416-421

Bingham T (2010) The rule of law. Allen Lane, London

Brown C, Scott C (2011) Regulation, public law, and better regulation. Eur Public Law 17:467-484

Cecot C, Hahn RW, Renda A, Schrefler L (2008) An evaluation of the quality of impact assessment in the European Union with lessons for the US and the EU. Regul Gov 2:405-424

Cimini C (2005) Principles of non-arbitrariness: lawlessness in the administration of welfare. Rutgers Law Rev 57:451-530

Davis K, Kingsbury B, Merry S (2012) Indicators as a technology of global goverance. Law Soc Rev 46:71-103

Dunlop CA, Maggetti M, Radaelli CM, Russel D (2012) The many uses of regulatory impact assessment: a meta-analysis of EU and UK cases. Regul Gov 6:23-45

Gyöngyi PM (2013) Fundamental principles of the European Union and judicial reforms in new member states: assessing judicial reforms in Hungary. Eur Public Law Organ, Athens

Hertin J, Jacob K, Pesch U, Pacchi C, Renda A (2009) The production and use of knowledge in regulatory impact assessment-an empirical analysis. For Policy Econ 11:413-421

Kingsbury B (2009) The concept of 'law' in global administrative law. Eur J Int Law 20:23-57

Koch DJ (2014) De Congo codes. Prometheus, Amsterdam

Krygier M (2009) The rule of law: legality, teleology, sociology. In: Palombella G, Walker N (eds) Relocating the rule of law. Hart, Oxford, pp 45-70

Krygier M (2011) Four puzzles about the rule of law: why, what, where? And who cares? In: Fleming J (ed) Getting to the rule of law. New York University Press, New York, pp 64-104

Krygier M (2012) Why the rule of law is too important to be left to lawyers. Prawo y Wiez 2(2):30-52

Lane Scheppele K (2013) The rule of law and the Frankenstate: why governance checklists do not work. Governance: an International Journal of Policy. Adm Inst 26:559-562

Mak E (2008) The European judicial organisation in a new paradigm: the influence of principles of "new public management" on the organisation of the European courts. Eur Law J 14:718-734

Marxsen C (2015) Open stakeholder consultations at the European level-voice of the citizens? Eur Law J 21:257-280

Merry S, Davis K, Kingsbury B (eds) (2015) The quiet power of indicators. Measuring governance, corruption and rule of law, Cambridge University Press, Cambridge.

Meuwese A, Popelier P (2011) Legal implications of better regulation: a special issue. Eur Public Law 17:455-466

Mohr R, Contini F (2014) Conflicts and commonalities in judicial evaluation. Oñati Soc Leg Ser 5:843-862 
Radaelli C, Meuwese A (2010) Hard questions, hard solutions: proceduralisation through impact assessment in the EU. West Eur Politics 33:136-153

Raz J (1979) The authority of law. Clarendon, Oxford

Selznick P (1961) Sociology and natural law. Nat Law Forum 6:84-108

Selznick P (1999) Legal cultures and the rule of law. In: Krygier M, Czarnota A (eds) The rule of law after communism. Ashgate, Dartmouth, pp 21-38

Selznick P (2003) 'Law in context' revisited. J Law Soc 30:177-186

Selznick P, Nonet P, Vollmer H (1969) Law, society and industrial justice. Russell Sage Foundation, New York

Serban M (2015) Rule of law indicators as a technology of power in Romania. In: Merry S, Davis K, Kingsbury B (eds) The quiet power of indicators. Measuring governance, corruption and rule of law. Cambridge University Press, Cambridge, pp 199-221

Taekema S (2013) The procedural rule of law: examining Waldron's argument on dignity and agency. Jahrbuch für Recht und Ethik/Annu Rev Law Ethics 21:133-146

Tamanaha B (2004) On the rule of law: history, politics, theory. Cambridge University Press, Cambridge Urueña R (2015) Indicators and the law. A case study of the rule of law index. In: Merry S, Davis K, Kingsbury B (eds) The quiet power of indicators. Measuring governance, corruption and rule of law. Cambridge University Press, Cambridge, pp 75-102

Waldron J (2008) The concept and the rule of law. Ga Law Rev 43:1-61

Wolff S (2013) The rule of law in the area of freedom, security and justice: monitoring at home what the European Union preaches abroad. Hague J Rule Law 5:119-131 